\title{
1 Comparative In-Vitro Physicochemical Evaluation 2 and Dissolution Profiling of Glibenclamide 5mg tablet 3 Marketed in Addis Ababa, Ethiopia
}

4

5 Selass Kebede ${ }^{1 \uparrow^{*}}$, Habtamu Abuye ${ }^{1 \&}$, Woldemichael Abraham ${ }^{2 \&}$, Sultan Suleman ${ }^{3 \&}$

6 and Sileshi Belew ${ }^{3 \&}$

$7 \quad{ }^{1}$ Department of Pharmacy, College of Medicine and Health Sciences, Wachemo

8 University

9 2Department of Pharmacy, College of Medicine and Health Sciences, Walayita Sodo

10 University

11 SSchool of Pharmacy, Institute Health Sciences, Jimma University

12

13 *Selass Kebede

14 E-mail: kselass@gmail.com (SK)

15

16 Selass Kebede, Habtamu Abuye, Woldemichael Abraham, Sultan Suleman and

17 Sileshi Belew

18 


\section{Abstract}

22 The safety of medicines is an essential part of patient safety. Global drug safety

23 depends on strong national systems that monitor the development and quality of

24 medicines. Poor quality medicines do not meet official standards for strength, quality,

25 purity, packaging and labelling. Hence, this study determines in-vitro quality

26 attributes of glibenclamide 5mg tablet marketed in Addis Ababa according to USP-38

27 drug monograph specifications. All tested brands meet the requirements for physical

28 inspection \& complied specification for friability and hardness. Besides, the tested

29 brands met USP 38 specification for assay (99.96\% to 108.85\%) and for content

30 uniformity (AV values ranges from 3.35 to 10.04). In-vitro release tests were carried

31 out in phosphate buffer of 7.5 and $8.5 \mathrm{pH}$ and showed drug release of $\geq 75 \%$, met

32 USP 38 requirements. However, significant difference with respect to dissolution

33 profile among tested brands GL4 and GL6 were confirmed with comparator product

34 through model independent approach. Moreover, DE values were studied and

35 confirmed that GL4 and GL6 were not therapeutically interchangeable with innovator

36 product. 


\section{Introduction}

39 Glibenclamide, which is also Glyburide in USA, is a second-generation sulfonylurea 40 oral hypoglycemic agent used in the treatment of noninsulin-dependent diabetes. It is

41 a Biopharmaceutical classification system (BCS) class II drug that has high 42 permeability and poor water solubility (Figure 1).[1] It is one of the most prescribed 43 long-acting anti-hyperglycemic agents that lower the blood glucose acutely by 44 stimulating the release of insulin from the pancreas, an effect dependent upon 45 functioning beta cells in the pancreatic islets. [2]

Figure 1. Chemical structure of Glibenclamide

The food and Drug Administration (FDA) has dictated that in order for the generic drugs to be approved, they have to pass many guided tests and examination for their physicochemical characteristics, contain the same active constituents and strength, in addition, to be bioequivalent to their innovator product. [3]

The quality concern of drugs is as old as drugs themselves. Despite all the advances made over the years, this concern has not disappeared. In the recent past, the unregulated proliferation of pharmaceutical industries and products has brought with it many diverse problems of varying magnitude. [4] The use of ineffective, poor quality, harmful medicines can result in therapeutic failure, exacerbation of disease, resistance to medicines and sometimes death. It also undermines confidence in health systems, health professionals, pharmaceutical manufacturers and distributors. Money

61 spent on ineffective, poor quality medicines is wasted - whether by consumers or governments. [5]

The safety, efficacy, and quality of the medicines should be ascertained to provide a desired pharmacological effect. Substandard drugs have been defined as those which do not meet quality specifications set for them, as to contain under or over

67 concentration of ingredients, contamination, poor quality ingredients, poor stability and inadequate packaging. [6] 
Many studies have shown the presences of substandard drugs available in the markets of several countries and significant difference in the dissolution and disintegration of tablets were revealed. A study conducted in Jordan indicated that generic Glibenclamide products exhibits a significant difference in their dissolution profile when compared to innovator products and 60\% ( 3 of 5) tested generics were found to be out of British pharmacopoeia specification for assay values. [7] Besides, a study done in Saud Arabia pointed out that 100\% (5 of 5), 60\% (3 of 5) and 20\% (1 of 5) of tested Glibenclamide products fails to release $\geq 75 \%$ of their content at $\mathrm{PH}$ value of 7.4, 7.8 and 9.5 respectively after one hour. [8] Moreover, 13 of 142 Glibenclamide tablet formulation from 28 countries (from Europe, north and South America, Africa, Asia and Australia) showed marked differences in in-vitro dissolution behavior. [9]

Ethiopian Food, Medicine and Health care Administration and Control Authority drug registration guideline requires every generic product to have a valid bioequivalence study that demonstrates its equivalence to the originator brand. Few studies done on the country, however, revealed that circulation of low quality medicines in its jurisdiction. A nationwide study on anthelminthic and antiprotozoal preparations available in Ethiopia market reported that $45.3 \%$ of tested samples were unable to comply pharmacopoeias specifications. [10] Gebrezgabiher et al localized study also showed $16.67 \%$ menbendazol tablet failed for disintegration \& dissolution test. [11] In the same vicinity, study conducted on ciprofloxacin indicated that $16.67 \%$ failed to release $80 \%$ within 30. [12] Additionally, Lantider $\mathrm{k}$. et al reported $62.5 \%$ amoxicillin marketed in that area was not pharmaceutically interchangeable. [13]

This findings are few evidences that Ethiopian health system endangered with poor quality medicines circulation within its drug supply chain system. Hence, the objective of the present study was to determine the physicochemical quality and dissolution profiling of imported and locally manufactured Glibenclamide $5 \mathrm{mg}$ tablets marketed in Addis Ababa, Ethiopia. 


\section{Materials and methods}

\section{Materials}

\section{Chemicals}

104 Reference standard of glibenclamide was obtained from Cadila Pharmaceutical

105 Manufacturing private limited company (Addis Ababa, Ethiopia). High-performance

106 liquid chromatography (HPLC) grade acetonitrile and methanol, potassium di107 hydrogen orthophosphate, monobasic ammonium phosphate, sodium hydroxide, 108 phosphoric acid \& Di-ionized water were obtained from Jimma University Laboratory 109 of Drug Quality-JuLaDQ (Jimma, Ethiopia).

\section{Apparatus}

111 The Agilent series HPLC system (Germany) employed in this study consisted of a 112 Diode array/ Ultra violet (UV) detector (Merck-Agilent, model Agilent 1260), a 113 quaternary pump (Merck-Agilent, model Agilent 1260), an integrator unit (Merck114 Agilent, model Agilent 1260) and equipped with chem. Station 32 software. The 115 employed HPLC column was C18, $5 \mu \mathrm{m}$ particle size, $150 \mathrm{~mm}$ length and $4.6 \mathrm{~mm}$ 116 internal diameter (Thermo Scientific, USA). Dissolution experiments were carried out 117 using a RC-6D Tian Jin scientific dissolution apparatus manufactured in China and 118 Cecil Aquarius UV-Visible spectrometer (England). Friability testing was carried out 119 using Pharma PTFE Friabilator (Germany). Hardness test was carried out using three 120 in one Pharma PTB hardness tester. Measurements of $\mathrm{pH}$ were made using AD1020 $121 \mathrm{PH} / \mathrm{mv} / \mathrm{ISE}$ and Temperature meter (Hungary). Weighing was done by using 122 METTELER TOLEDO analytical weight balance (Switzerland). Water purification 123 was done by using water distiller and de-ionizer instrument.

\section{Methods}

125 The In-vitro critical quality attributes of the glibenclamide $5 \mathrm{mg}$ tablets were assessed 126 according to USP-38 monograph specification. [14] Besides, additional in-vitro 127 quality control parameters were used to investigation the products. 


\section{Identification}

130 The retention time of the major peak of the sample solution was compared with that

131 of the standard solution as stated in the USP/NF 38 drug monograph. [14]

\section{Assay and content uniformity}

133 Standard preparation

$13410 \mathrm{mg}$ of working standard was weighed using verified analytical balance and put

135 in to $25 \mathrm{ml}$ volumetric flask. Acetonitrile equivalent to $20 \mathrm{ml}$ was added and

136 shacked. Then, water equivalent to $0.4 \mathrm{ml}$ per $\mathrm{mg}$ of Glibenclamide was added 137 and shacked for 30 minutes. [14] Then, the solution was used to check system 138 suitability of the methods.

140 Sample preparation

141 Ten tablets from each sample were taken and placed individually in a suitable 142 container. Water equivalent to $0.4 \mathrm{ml}$ per $\mathrm{mg}$ of glyburide was added and swirled to 143 disperse and wet tablet material. Then acetonitrile equivalent to $2.0 \mathrm{ml}$ per $\mathrm{mg}$ of 144 glyburide was added and shaken for $30 \mathrm{~min}$. [14] The suspension was centrifuged and 145 the clear supernatant was used.

147 Chromatographic system

148 The liquid chromatographic system equipped with a 254-nm detector and 4.6-mm $\mathrm{x}$ 149 150-cm column that contains packing L7 having flow rate of $2 \mathrm{ml}$ per minute with 10 $150 \mu$ injection volume was used to carry out the assay measurement. [14]

152 The analysis result was computed with the following formula:

$$
\text { Result }=\left(\frac{R u}{R s}\right) \times\left(\frac{C s}{C u}\right) \times 100
$$

154 Where; $R_{u}$ is response of unknown sample, $R_{s}$ is response of reference standard

$155 \mathrm{C}_{\mathrm{s}}$ is concentration of the reference standard; $\mathrm{C}_{\mathrm{u}}$ is concentration of unknown sample

\section{Dissolution}

157 The tests were performed according to pharmacopoeia specifications using Apparatus

1582 (paddle method). The medium employed was $900 \mathrm{ml}$ of $0.05 \mathrm{M}$ phosphate buffer of $159 \mathrm{pH} 7.5$ and 8.5. Medium temperature was set at $37^{\circ} \mathrm{C} \pm 0.2^{\circ} \mathrm{C}$. Six tablets of each 160 product were placed in the dissolution apparatus (one in each vessel). Samples $(5 \mathrm{ml})$ 
161 were withdrawn at pre-determined time points $(5,15,30,45$ and 60 at $7.5 \mathrm{pH} ; 5,15$,

16230 and 45 at $8.5 \mathrm{pH}$ ) and the withdrawn samples were replaced with respective buffer

163 solution. All samples were then filtered before being measured. HPLC system

164 equipped with a 254-nm detector and 4.6-mm x 25-cm column that contains packing

165 L7 for buffer medium of $7.5 \mathrm{pH}$ and HPLC system equipped with a 215-nm detector

166 and 4.6-mm x 25-cm column that contains packing $\mathrm{L} 7$ for buffer medium of $8.5 \mathrm{pH}$

167 was used to carry out the dissolution measurement. The flow rate was adjusted at $2 \mathrm{ml}$

168 per minute and with $75 \mu \mathrm{l}$ injection volumes for $7.5 \mathrm{pH}$ buffer medium and $1.5 \mathrm{ml}$ per

169 minute and with $50 \mu \mathrm{l}$ injection volumes for $8.5 \mathrm{pH}$ buffer medium. The systems were

170 functioned with relative standard deviation of NMT 2.0\% for replicate injection. [14]

171 The amount of dissolved glibenclamide was determined using the regression equation

172 computed with reference sample with the same buffer type.

174 The analysis result was computed using the following formula:

$$
\% \text { Release }=\left(\frac{A u}{A s}\right) \times\left(\frac{C s}{L c}\right) \times \text { Disn.V } \times 100
$$

176 Where; $A_{u}$ is peak response of the sample, $A_{s}$ is peak response of the reference

$177 \mathrm{C}_{\mathrm{s}}$ is concentration of the reference, $\mathrm{L}_{\mathrm{c}}$ is label claim, $\mathrm{V}$ is dissolution volume

178 And, using regression equation:

$$
y=m x \pm b
$$

180 Where; $\mathrm{m}$ is the slope, $\mathrm{b}$ is the intercept

182 The dissolution pattern of the drug was analyzed using both model-dependent 183 methods - zero order, first order, Weibull approach, Hugichi, Hickson-crowell and 184 Korsmeyer-Peppas; and model-independent methods-fit factors were used to 185 compare similarity and dissimilarity between tested brands and comparator. [15 \& 16]

186 Model-dependent method equations:

$$
Q_{t}=Q_{0}-k_{0} t \ldots \ldots \ldots \ldots . . . . \text { zero order }
$$

$$
\log Q_{t}=\log Q_{0}-\frac{k t}{2.303} \ldots . . . \text { first order }
$$

$$
M_{0}^{\frac{1}{3}}-M_{t}^{\frac{1}{3}}=\kappa t \ldots . . . \text { Hickson-crowell }
$$

$$
Q_{t}=K_{h} t^{\frac{1}{2}} \ldots \ldots . \text { Hugichi }
$$

$$
\ln (y)=a * \ln (x)+b \ldots . . \text { Korsmeyer-Peppas }
$$


192

193

194

\section{Friability}

196 Twenty tablets from each brand were weighed individually and subjected to abrasion

197 using a tablet friability tester at 25 revolutions per minute for 4 minutes. The tablets

198 were weighed again and the difference in weight will be calculated as the percentage.

199 A maximum weight loss of not more than $1 \%$ of the weight of the tablets being tested

200 are not allowed.

201

202

203

204

205

\section{Uniformity of weight}

207 Twenty tablets from each of the brand was weighed individually using analytical

208 balance. The average weights of the tablets for individual brand and their deviation

209 from the average weight was calculated.

210 And \% of weight variation was calculated using the following formula:

$$
\% \text { of Wt.Variation }=\frac{\text { Wx-Wav. }}{\text { Wav. }} \times 100 \%
$$

212 Where $\mathrm{W}_{\mathrm{x}}$ is individual weight, $\mathrm{W}_{a v}$. is average weight tested tablets,

\section{Crushing strength/Hardness}

214 Hardness of individual brand drugs was obtained by measuring the crushing strength 215 of ten randomly selected tablets using hardness tester. Then the mean and standard deviation was calculated. 


\section{System verification}

\section{Method accuracy/recovery}

219 As indicated in International Conference on Harmonization (ICH) guideline Q2B, 220 system recovery was done by adding known amount of standard in the blank. The 221 working standard has been prepared in three different concentrations (one from the 222 lower, one from the middle and one from the higher amount) with in the range of $70 \%$ 223 to $130 \%$ concentration. Each of the three concentrations $(78 \%, 104 \%$ and $119 \%)$ has 224 been injected in triplicated manner in to the HPLC system and \% recovery for 225 individual concentration has been computed. Since the difference in \% recovery 226 values at each concentration becomes less than $2 \%$ which is the maximum limit set in 227 the ICH Q2B guideline, the system was proved to be fit for the purpose. [17] The 228 result of recovery tests were presented in Table 1.

230 Table 1. System Accuracy/recovery test result at 3 different concentration $(n=3)$.

\begin{tabular}{|l|l|l|l|l|l|}
\hline Theoretical value & $\begin{array}{l}\% \\
\text { value }\end{array}$ & $\begin{array}{l}\text { Measured } \\
\text { value }\end{array}$ & $\%$ recovery & $\begin{array}{l}\text { Difference in } \\
\% \text { recovery }\end{array}$ & $\begin{array}{l}\text { Acceptance } \\
\text { limit } \pm 2 \%\end{array}$ \\
\hline 78 & 100 & 77.99 & 99.99 & 0.01 & pass \\
\hline 104 & 100 & 103.93 & 99.93 & 0.07 & pass \\
\hline 119 & 100 & 118.55 & 99.62 & 0.38 & pass \\
\hline
\end{tabular}

\section{Method Precision}

233 The repeatability of the method was checked by using prepared working standards at

234 three different concentrations of $90 \%, 100 \%$, and $110 \%$ within the range of $80 \%$ to $235120 \%$ as clearly stated in the ICH Q2B guideline. So, triplicate injections from each 236 concentration were injected to the system and the RSD for individual concentration 237 was computed. The calculated Relative Standard Deviation (RSD) values for 90\%, $238100 \%$ and $110 \%$ were $0.07,0.05$ and 0.20 respectively. Thus, the method is proved to 239 be fit for the purpose since the RSD values are below acceptable maximum limit of 2 240 as indicated in ICH Q2B. [17] The result of the repeatability tests were presented in 241 Table 2. 
247 Table 2. System Repeatability test result at 3 different concentration $(n=3)$.

\begin{tabular}{|c|c|c|c|c|c|c|c|}
\hline $\begin{array}{l}\% \\
\text { Conc. }\end{array}$ & Peak & $\begin{array}{l}\text { Peak } \\
\text { Avg. }\end{array}$ & $\%$ Conc. & $\begin{array}{l}\text { Avg. } \\
\text { Conc. }\end{array}$ & SD & RSD & $\begin{array}{l}\text { Acceptance } \\
\text { limit } \pm 2\end{array}$ \\
\hline 90 & 1561.92 & \multirow[t]{3}{*}{1560.75} & 90.39 & \multirow[t]{3}{*}{90.33} & \multirow[t]{3}{*}{1.02} & \multirow[t]{3}{*}{0.07} & \multirow[t]{3}{*}{ pass } \\
\hline 90 & 1560.04 & & 90.29 & & & & \\
\hline 90 & 1560.3 & & 90.30 & & & & \\
\hline 100 & 1818.98 & \multirow[t]{3}{*}{1818.37} & 103.96 & \multirow[t]{3}{*}{103.93} & \multirow[t]{3}{*}{0.81} & \multirow[t]{3}{*}{0.05} & \multirow[t]{3}{*}{ pass } \\
\hline 100 & 1818.67 & & 103.95 & & & & \\
\hline 100 & 1817.45 & & 103.88 & & & & \\
\hline 110 & 1922.54 & \multirow[t]{3}{*}{1918.27} & 109.43 & \multirow[t]{3}{*}{109.21} & \multirow[t]{3}{*}{3.75} & \multirow[t]{3}{*}{0.20} & \multirow[t]{3}{*}{ pass } \\
\hline 110 & 1916.74 & & 109.12 & & & & \\
\hline 110 & 1915.51 & & 109.06 & & & & \\
\hline
\end{tabular}

\section{Method linearity}

250 The linearity of the method has been verified by using five different concentrations

251 within the range of $80 \%$ to $120 \%$. Triplicate injection from each concentration has

252 been injected to the system and RSD for individual concentration were computed. The

253 system was found to be fit for the purpose as the calculated RSDs for all

254 concentration become less than $2 \%$ which is the maximum acceptable limit stated in

255 ICH Q2B guideline. [17] The result of linearity tests for assay and content uniformity

256 method was indicated in Fig 2.

Figure 2. System linearity test result at 5 different concentration $(n=3)$.

260 For a dissolution test, methods linearity was computed by using regression equation:

$261 \mathrm{y}=\mathrm{mx} \pm \mathrm{b}$; where; $\mathrm{m}$ is the slope, $\mathrm{b}$ is the intercept. For buffer medium of $7.5 \mathrm{pH}$ the

262 regression equation was $\mathrm{y}=0.008 \mathrm{x}+0.0919$ with regression coefficient $\left(r^{2}\right)$ of 0.9153

263 whereas at $8.5 \mathrm{pH}$ buffer the regression equation was $\mathrm{y}=0.004 \mathrm{x}+0.2321$ with 264 regression coefficient $\left(r^{2}\right)$ of 0.9876 . Thus, the method was found to be suitable for 265 the analysis.

\section{Statistical Analysis}

267 Assessment of quality of each sample was performed according to the test method 268 described in standard pharmacopeia (USP-38). The data generated were subjected to 
269 appropriate software's such as excel-2010, Minitab and kinetic DS. In addition both

270 model dependent and model independent approaches were used to compare

271 dissolution profile between the Innovator and generic brands of glibenclamide $5 \mathrm{mg}$

272 tablet.

\section{Results and discussion}

274 Glibenclamide 5mg tablet products were purchased from the local drug retail

275 outlets/health facilities in Addis Ababa, Ethiopia in the same way that the patient

276 might have bought them from such facilities by using mystery shoppers during the

277 study period. The product information of glibenclamide $5 \mathrm{mg}$ tablet included in the

278 study was presented in Table 3 with their full description.

279

280 Table 3. Product information of different brands of Glibenclamide tablet included in

281 the study.

\begin{tabular}{|c|c|c|c|c|c|c|c|}
\hline Brand name & $\begin{array}{l}\text { Batch } \\
\text { number }\end{array}$ & $\begin{array}{l}\text { Manufactu } \\
\text { ring date }\end{array}$ & $\begin{array}{l}\text { Expiry } \\
\text { date }\end{array}$ & $\begin{array}{l}\text { Quantity } \\
\text { purchased }\end{array}$ & Manufacturer & Origin & $\begin{array}{l}\text { Product } \\
\text { Code }\end{array}$ \\
\hline $\begin{array}{l}\text { GLAMIDE }^{\circledR} \\
5 \mathrm{mg}\end{array}$ & $\begin{array}{l}\text { D14012B } \\
\text { X75 }\end{array}$ & Dec 2014 & $\begin{array}{l}\text { Nov } \\
2018\end{array}$ & 200 & $\begin{array}{l}\text { Cadila } \\
\text { pharmaceuticals } \\
\text { plc. }\end{array}$ & Ethiopia & GL1 \\
\hline Melix ${ }^{\circledR} 5 \mathrm{mg}$ & E028 & $08 / 2014$ & $\begin{array}{l}08 / 201 \\
9\end{array}$ & 200 & $\begin{array}{l}\text { Boss } \\
\text { pharmaceuticals }\end{array}$ & Switzerland & GL2 \\
\hline Glitisol ${ }^{\circledR} 5 \mathrm{mg}$ & 65226 & $07 / 2015$ & $\begin{array}{l}07 / 202 \\
0\end{array}$ & 200 & Remedical ltd. & Cyprus & GL3 \\
\hline $\begin{array}{l}\text { Glynase }{ }^{\circledR} \\
5 \mathrm{mg}\end{array}$ & 25 & $01 / 2016$ & $\begin{array}{l}12 / 201 \\
8\end{array}$ & 200 & $\begin{array}{l}\text { Julphar } \\
\text { pharmaceutical } \\
\text { plc. }\end{array}$ & Ethiopia & GL4 \\
\hline Daolin $^{\circledR} 5 \mathrm{mg}$ & SJ15E & $11 / 2015$ & $\begin{array}{l}10 / 201 \\
7\end{array}$ & 200 & Sanofi industries & France & GL5 \\
\hline $\begin{array}{l}\text { BETANASE }^{\circledR} \\
5 \mathrm{mg}\end{array}$ & GN1029 & $01 / 2013$ & $\begin{array}{l}12 / 201 \\
6\end{array}$ & 200 & $\begin{array}{l}\text { Cadila } \\
\text { healthcare ltd. }\end{array}$ & India & GL6 \\
\hline
\end{tabular}

282

284 The physical characteristics of the product are a predetermining factor that influences

285 the dissolution behavior and API content of the drugs. As a result, significant

286 difference in the physical characteristics among different brands of a given drug

287 results in great variation in the efficacy of the drug which leads to either treatment

288 failure and/or toxicity to the patients. [9] As indicated in Table 4, tested glibenclamide

289 brands comply for physical characteristics, packaging and labelling information 
requirements. Similar results have been reported for compliance in packaging and

labeling in different countries. [7-9]

293 Table 4. Physical characteristics and packaging and labelling information of samples

294 of different glibenclamide medicines.

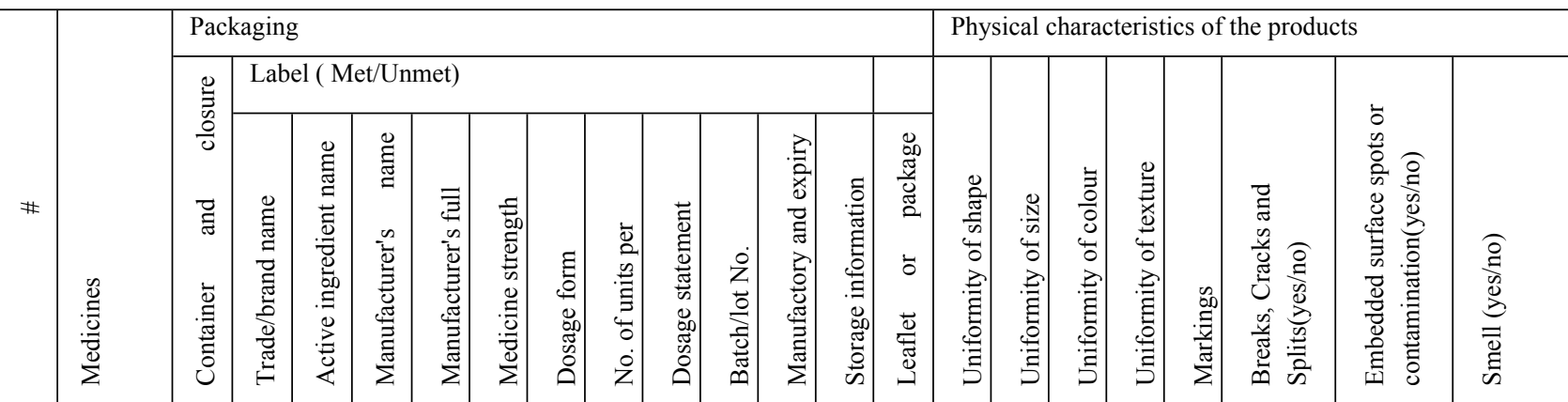

\footnotetext{
Glibenclamide brands
}

\begin{tabular}{|l|l|l|l|l|l|l|l|l|l|l|l|l|l|l|l|l|l|l|l|l|l|l|}
\hline 1 & $\begin{array}{l}\text { GLAM } \\
\text { IDE }^{\circledR}\end{array}$ & $\begin{array}{l}\mathrm{M} \\
\text { et }\end{array}$ & $\begin{array}{l}\mathrm{M} \\
\text { et }\end{array}$ & $\begin{array}{l}\mathrm{M} \\
\text { et }\end{array}$ & $\begin{array}{l}\mathrm{M} \\
\text { et }\end{array}$ & $\begin{array}{l}\mathrm{M} \\
\text { et }\end{array}$ & $\begin{array}{l}\mathrm{M} \\
\text { et }\end{array}$ & $\begin{array}{l}\mathrm{M} \\
\text { et }\end{array}$ & $\begin{array}{l}\mathrm{M} \\
\text { et }\end{array}$ & $\begin{array}{l}\mathrm{M} \\
\text { et }\end{array}$ & $\begin{array}{l}\mathrm{M} \\
\text { et }\end{array}$ & $\begin{array}{l}\mathrm{M} \\
\text { et }\end{array}$ & $\begin{array}{l}\mathrm{M} \\
\text { et }\end{array}$ & $\begin{array}{l}\mathrm{M} \\
\text { et }\end{array}$ & $\begin{array}{l}\mathrm{M} \\
\text { et }\end{array}$ & $\begin{array}{l}\mathrm{M} \\
\text { et }\end{array}$ & $\begin{array}{l}\mathrm{M} \\
\text { et }\end{array}$ & $\begin{array}{l}\mathrm{M} \\
\text { et }\end{array}$ & $\begin{array}{l}\mathrm{M} \\
\text { et }\end{array}$ & $\mathrm{No}$ & $\mathrm{No}$ \\
\hline 2 & Melix $^{\circledR}$ & $\begin{array}{l}\mathrm{M} \\
\text { et }\end{array}$ & $\begin{array}{l}\mathrm{M} \\
\text { et }\end{array}$ & $\begin{array}{l}\mathrm{M} \\
\text { et }\end{array}$ & $\begin{array}{l}\mathrm{M} \\
\text { et }\end{array}$ & $\begin{array}{l}\mathrm{M} \\
\text { et }\end{array}$ & $\begin{array}{l}\mathrm{M} \\
\text { et }\end{array}$ & $\begin{array}{l}\mathrm{M} \\
\text { et }\end{array}$ & $\begin{array}{l}\mathrm{M} \\
\text { et }\end{array}$ & $\begin{array}{l}\mathrm{M} \\
\text { et }\end{array}$ & $\begin{array}{l}\mathrm{M} \\
\text { et }\end{array}$ & $\begin{array}{l}\mathrm{M} \\
\text { et }\end{array}$ & $\begin{array}{l}\mathrm{M} \\
\text { et }\end{array}$ & $\begin{array}{l}\mathrm{M} \\
\text { et }\end{array}$ & $\begin{array}{l}\mathrm{M} \\
\text { et }\end{array}$ & $\begin{array}{l}\mathrm{M} \\
\text { et }\end{array}$ & $\begin{array}{l}\mathrm{M} \\
\text { et }\end{array}$ & $\begin{array}{l}\mathrm{M} \\
\text { et }\end{array}$ & $\begin{array}{l}\mathrm{M} \\
\text { et }\end{array}$ & $\mathrm{No}$ & $\mathrm{No}$ & $\mathrm{No}$ \\
\hline
\end{tabular}

\begin{tabular}{|c|c|c|c|c|c|c|c|c|c|c|c|c|c|c|c|c|c|c|c|c|c|c|}
\hline & & et & et & et & et & et & et & et & et & et & et & et & et & et & et & et & et & et & et & & & \\
\hline 3 & Glitisol & $\begin{array}{l}\mathrm{M} \\
\text { et }\end{array}$ & $\begin{array}{l}\mathrm{M} \\
\text { et }\end{array}$ & $\begin{array}{l}\mathrm{M} \\
\text { et }\end{array}$ & $\begin{array}{l}\mathrm{M} \\
\text { et }\end{array}$ & $\begin{array}{l}\mathrm{M} \\
\text { et }\end{array}$ & $\begin{array}{l}\mathrm{M} \\
\text { et }\end{array}$ & $\begin{array}{l}\mathrm{M} \\
\text { et }\end{array}$ & $\begin{array}{l}\mathrm{M} \\
\text { et }\end{array}$ & $\begin{array}{l}\mathrm{M} \\
\text { et }\end{array}$ & $\begin{array}{l}\mathrm{M} \\
\text { et }\end{array}$ & $\begin{array}{l}\mathrm{M} \\
\text { et }\end{array}$ & $\begin{array}{l}\mathrm{M} \\
\text { et }\end{array}$ & $\begin{array}{l}\mathrm{M} \\
\text { et }\end{array}$ & $\begin{array}{l}\mathrm{M} \\
\text { et }\end{array}$ & $\begin{array}{l}\mathrm{M} \\
\text { et }\end{array}$ & $\begin{array}{l}\mathrm{M} \\
\text { et }\end{array}$ & $\begin{array}{l}\mathrm{M} \\
\text { et }\end{array}$ & $\begin{array}{l}\mathrm{M} \\
\text { et }\end{array}$ & No & $\mathrm{No}$ & $\mathrm{No}$ \\
\hline 4 & Glynas & M & M & M & M & M & M & M & M & $\begin{array}{l}\mathrm{M} \\
\text { et }\end{array}$ & $\begin{array}{l}\text { M } \\
\text { et }\end{array}$ & $\begin{array}{l}\text { M } \\
\text { et }\end{array}$ & $\begin{array}{l}\text { M } \\
\text { et }\end{array}$ & $\begin{array}{l}\text { M } \\
\text { et }\end{array}$ & $\begin{array}{l}\text { M } \\
\text { et }\end{array}$ & $\begin{array}{l}\text { M } \\
\text { et }\end{array}$ & $\begin{array}{l}\text { M } \\
\text { et }\end{array}$ & $\begin{array}{l}\text { M } \\
\text { et }\end{array}$ & $\begin{array}{l}\text { M } \\
\text { et }\end{array}$ & $\mathrm{No}$ & No & $\mathrm{No}$ \\
\hline 5 & Daolin & $\mathrm{M}$ & $\mathrm{M}$ & $M$ & $M$ & $\mathrm{M}$ & $\mathrm{M}$ & $\mathrm{M}$ & $\mathrm{M}$ & $\mathrm{M}$ & $M$ & $M$ & $\mathrm{M}$ & $M$ & $M$ & $M$ & $\mathrm{M}$ & $\mathrm{M}$ & $\mathrm{M}$ & $\mathrm{No}$ & $\mathrm{No}$ & $\mathrm{No}$ \\
\hline
\end{tabular}

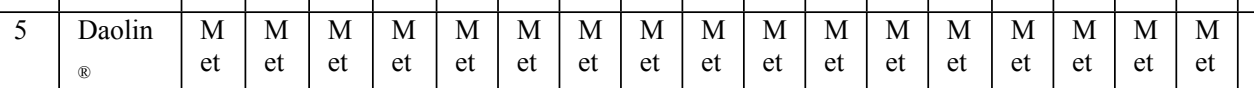

\section{Identification test}

297 The identification test was conducted according USP 38 drug monograph

298 specification. A reasonable peak shape was obtained for the analyte as per system 299 suitability requirements. The identity of tested products was confirmed by comparing their retention time with that of glibenclamide working standard. [14] As indicated in

301 Figs 3-5, tested glibenclamide products exhibited practically similar retention time 302 (Rt) values when compared to reference standard. Thus, it can be concluded that all 303 the tested glibenclamide products contains correct active ingredient.

Figure 3. Blank chromatogram 


\section{Assay for API}

309 All six brands of Glibenclamide 5mg tablet were assayed as indicated in USP 38

310 monograph. [14] As presented in Table 5, the assay results of tested glibenclamide

311 brands were found to be within the range of $99.97 \%$ to $108.85 \%$ which was within

312 USP 38 assay specification (90\% to 110\%). However, brands GL1 and GL6 failed to

313 pass British Pharmacopeia (BP) and European Pharmacopeia (Ph.Eur) specifications

314 for assay (95\% to $105 \%$ ). There were reports of similar incidents that showed some of

315 the generics were not in line with BP, Ph.Eur. and International Pharmacopeia (Ph.

316 Int.) specification for their API contents. [7] Among all tested glibenclamide products,

317 GL1 had higher assay value of $108.85 \%$ whereas GL5 had lower assay value of $31899.97 \%$.

Table 5. Average percentage per label obtained for each tested product.

\begin{tabular}{|c|c|c|c|c|}
\hline Product Name & $\begin{array}{l}\text { Product } \\
\text { code }\end{array}$ & Assay Avg. & RSD of assay & $\begin{array}{l}\text { Reference Acceptance } \\
\text { limit USP (90-110) }\end{array}$ \\
\hline GLAMIDE $^{\circledR} 5 \mathrm{mg}$ & GL1 & 108.85 & 0.17 & Pass \\
\hline Melix ${ }^{\circledR} 5 \mathrm{mg}$ & GL2 & 101.08 & 0.08 & Pass \\
\hline Glitisol ${ }^{\circledR} 5 \mathrm{mg}$ & GL3 & 102.19 & 0.16 & Pass \\
\hline Glynase $^{\circledR} 5 \mathrm{mg}$ & GL4 & 101.05 & 0.12 & Pass \\
\hline Daolin $^{\circledR} 5 \mathrm{mg}$ & GL5 & 99.96 & 0.47 & Pass \\
\hline $\begin{array}{l}\text { BETANASE }^{\circledR} \\
5 \mathrm{mg}\end{array}$ & GL6 & 105.52 & 0.05 & Pass \\
\hline
\end{tabular}

322 The difference in the assay values between tested generics and comparator product 323 were assessed using annova single factorial analysis at 95\% CI. The calculated P 324 value and $\mathrm{F}$ value were found to be 6.41584E-21 (lower than expected value of 0.05 ) 325 and 896.65 (higher than Fcrit value of 2.772853153) respectively. Both $\mathrm{P}$ and $\mathrm{F}$ 326 values indicated as there is significant difference among assay value of tested brands. 327 Post ANNOVA t-tests with Bonferroni correction were used to indicate the brands 328 that have significant difference from the comparator. Thus, except GL4, the mean 329 assay values of all generics were found to have significant difference with comparator 330 product since the T stat value of GL1, GL2, GL3 and GL6 were 34.86, 4.64, 8.89 and 33123.35 respectively which were greater than the $\mathrm{T}$ critical value of comparator GL5 332 (which was 2.31). This has been confirmed with calculated $\mathrm{P}$ value of the products that become less than the Bonferroni corrected expected $\mathrm{P}$ value at 95\% CI. 


\section{Content uniformity}

335 The content uniformity test was performed as per USP 38 specification for all 336 glibenclamide tablets and the acceptance value was calculated. [14] The acceptance 337 values for all brands were found to be less than 15 (the maximum allowed acceptance 338 value, L1) as shown in Table 6. Thus, it can be concluded that all brands comply 339 USP-38 requirements for content uniformity.

340 Table 6. Content uniformity test result $(n=10)$.

\begin{tabular}{|l|l|l|l|}
\hline Product code & $\begin{array}{l}\text { Calculated } \\
\text { acceptance value }\end{array}$ & $\begin{array}{l}\text { Maximum allowed } \\
\text { AV value L1=15 }\end{array}$ & Reference \\
\hline GL1 & 8.42 & Pass & \multirow{2}{*}{ USP-38 } \\
\hline GL2 & 10.04 & Pass & \\
\cline { 1 - 2 } GL3 & 5.78 & Pass & \\
\hline GL4 & 4.71 & Pass & \\
\hline GL5 & 3.35 & Pass & \\
\cline { 1 - 2 } GL6 & 6.18 & Pass & \\
\hline
\end{tabular}

\section{Dissolution}

342 Dissolution test is a critical quality attribute parameter used to predict the in-vivo 343 performances of oral pharmaceutical solid dosage forms like tablets and capsules. 344 Besides, it can serve as a surrogate for bioavailability and bioequivalence. [18 \& 19]

345 In this study, dissolution tests were conducted with paddle dissolution apparatus as 346 specified in USP-38 monograph for glibenclamide tablet preparation using phosphate 347 buffer as a dissolution medium at 7.5 and $8.5 \mathrm{pH}$ values.

349 The dissolution profiles of tested products at $7.5 \mathrm{pH}$ phosphate buffer, as indicated in 350 Fig 6, were in line with pharmacopoeia requirements for percent drug release since all 351 tested brands exhibits drug release behavior of more than $75 \%$. Thus, it can be 352 concluded that all brands have passed dissolution criteria.

354 Figure 6. Dissolution profile of tested drugs at $7.5 \mathrm{pH}$ phosphate buffer.

356 The two way ANOVA analysis of the dissolution data at $45 \mathrm{~min}$ for all tested brands 357 showed that the dissolution behavior between different brands of glibenclamide tablet 358 were significantly different at $95 \%$ CI ( $\mathrm{F}>\mathrm{F}$ crit; $\mathrm{P}<0.05)$. Additionally, post 
ANOVA t-tests with Bonferroni correction were computed to point out which brands were not equivalent statistically with the comparator product with respect to their drug release profile at 95\% CI. GL1, GL2, GL3 and GL6 were found to be significantly different in their drug release phenomena from comparator (GL5) product at $45 \mathrm{~min}$ ( $\mathrm{t}$ stat $>$ t crit).

The dissolution profiles of the generic and the innovator products at $8.5 \mathrm{pH}$ phosphate buffer were presented in Fig 7. Since all tested brands exhibits drug release behavior of more than $75 \%$ at 30 minutes, it can be concluded that all tested glibenclamide tablets met USP-38 monograph requirements.

Figure 7. Dissolution profile of tested drugs at $8.5 \mathrm{pH}$ phosphate buffer

The two way ANOVA analysis performed at 95\% CI for the pharamacopoeially specified time, 30 minutes, found that there were significant differences in the release pattern of different glibenclamide brands $(\mathrm{F}>\mathrm{F}$ crit; $\mathrm{P}<0.05)$. As a result, post ANOVA t-tests with Bonferroni correction was done to observe the source of dissimilarity between comparator (GL5) and the tested generics at 95\% CI. This comparative analysis showed that GL4 and GL6 were significantly different in their drug release pattern at 30 min when compared with the comparator product.

\section{Dissolution profile evaluation}

380 Model-independent approach of difference factor $\left(f_{1}\right)$ and similarity factor $\left(f_{2}\right)$ was 381 computed for in-vitro dissolution profile studies to demonstrate the equivalence of all 382 the generic glibenclamide tablets and the comparator product. [19] To ensure 383 similarity and bioequivalence of two dissolution profiles, $f_{l}$ should be between 0 and 38415 whereas $f_{2}$ should be between 50 and 100. [15-16, 19] In both cases, GL1, GL2 and

385 GL3 were found to be similar in their dissolution behavior with comparator product 386 (GL5) whereas GL6 was not. The similarity and dissimilarity values of tested products at $\mathrm{pH}$ of 7.5 and 8.5 were presented in Table 7. As a result, both $f_{1}$ and $f_{2}$ values justifies interchangeability of GL1, GL2 and GL3 generics with the comparator product. On the other hand, GL4 and GL6 might not be bioequivalent and

390 therapeutically interchangeable with the comparator product (GL5).

391 Table 7. Similarity and dissimilarity factor comparison at $\mathrm{pH}$ of 7.5 and 8.5 


\begin{tabular}{|l|l|l|l|l|l|}
\hline \multirow{2}{*}{ Product code } & \multicolumn{2}{|l|}{ At pH of 7.5 } & \multicolumn{2}{l|}{ At pH of 8.5 } & \multicolumn{2}{|}{$\begin{array}{l}\text { Status (Expected } f_{2}>50 \text { and } \\
\left.f_{1}<15\right)\end{array}$} \\
\cline { 2 - 5 } & $f_{2}$ & $f_{1}$ & $f_{2}$ & $f_{1}$ & Similar \\
\hline GL5 vs GL1 & 62.09 & 7.63 & 68.36 & 5.20 & Similar \\
\hline GL5 vs GL2 & 79.95 & 2.99 & 66.80 & 5.82 & Similar \\
\hline GL5 vs GL3 & 91.39 & 1.30 & 83.49 & 2.30 & Dissimilar \\
\hline GL5 vs GL4 & 42.32 & 16.41 & 45.24 & 13.78 & Dissimilar \\
\hline GL5 vs GL6 & 48.25 & 14.44 & 48.90 & 13.51 & \\
\hline
\end{tabular}

393 In order to ascertain the interchangeability of all products with the comparator

394 product, drug release profiles of individual brands of Glibenclamide tablets were

395 analyzed different kinetics models. The result of kinetic model studies for dissolution

396 behaviors at pH 7.5 and 8.5 were presented in Table 8 and 9. The model that gives

397 high correlation coefficient ( $\mathrm{r} 2$ ) value is considered as the best fit model for the

398 dissolution data. [16] Based on the findings, the Korsmeyer-Peppas model was found

399 to best fit the dissolution data at both $\mathrm{pH}$ values. Therefore, it can be concluded that

400 all brands under the investigation showed the similar drug release mechanism.

401 Table 8. Correlation coefficient and DE values of kinetic models for dissolution data $402 \quad 7.5 \mathrm{pH}$

403

\begin{tabular}{|l|l|l|l|l|l|l|l|}
\hline $\begin{array}{l}\text { Product } \\
\text { code }\end{array}$ & 0 order & $\begin{array}{l}1^{\text {st }} \\
\text { order }\end{array}$ & Hugichi & $\begin{array}{l}\text { Hickson- } \\
\text { crowell }\end{array}$ & $\begin{array}{l}\text { Korsmeyer- } \\
\text { Peppas }\end{array}$ & \multicolumn{2}{|l|}{ Dissolution efficiency } \\
\hline & $\mathrm{r}^{2}$ & $\mathrm{r}^{2}$ & $\mathrm{r}^{2}$ & $\mathrm{r}^{2}$ & $\mathrm{r}^{2}$ & $\mathrm{DE}$ & MDT \\
\hline GL1 & 0.9187 & 0.8172 & 0.9696 & 0.8546 & 0.9975 & $6.50 \mathrm{E}+01$ & $1.73 \mathrm{E}+01$ \\
\hline GL2 & 0.8812 & 0.7741 & 0.9322 & 0.8122 & 0.9714 & $7.27 \mathrm{E}+01$ & $1.59 \mathrm{E}+01$ \\
\hline GL3 & 0.8902 & 0.7794 & 0.9388 & 0.8189 & 0.9721 & $7.07 \mathrm{E}+01$ & $1.64 \mathrm{E}+01$ \\
\hline GL4 & 0.9371 & 0.8413 & 0.9785 & 0.8775 & 0.9929 & $5.78 \mathrm{E}+01$ & $1.78 \mathrm{E}+01$ \\
\hline GL5 & 0.8919 & 0.7906 & 0.9421 & 0.8371 & 0.9787 & $7.06 \mathrm{E}+01$ & $1.61 \mathrm{E}+01$ \\
\hline GL6 & 0.9352 & 0.8356 & 0.9769 & 0.8729 & 0.9914 & $6.00 \mathrm{E}+01$ & $1.79 \mathrm{E}+01$ \\
\hline
\end{tabular}

404 Table 9. Correlation coefficient and DE values of kinetic models for dissolution data $405 \quad 8.5 \mathrm{pH}$

\begin{tabular}{|l|l|l|l|l|l|l|}
\hline Product & 0 order & $1^{\text {st }}$ & Hugichi & Hickson- & Korsmeyer- & Dissolution efficiency \\
\hline
\end{tabular}




\begin{tabular}{|l|l|l|l|l|l|l|l|}
\hline code & & order & & crowell & Peppas & \multicolumn{2}{l|}{} \\
\hline & $\mathrm{r}^{2}$ & $\mathrm{r}^{2}$ & $\mathrm{r}^{2}$ & $\mathrm{r}^{2}$ & $\mathrm{r}^{2}$ & DE & MDT \\
\hline GL1 & 0.9094 & 0.8448 & 0.7422 & 0.8676 & 0.9881 & $6.99 \mathrm{E}+01$ & $1.13 \mathrm{E}+01$ \\
\hline GL2 & 0.8814 & 0.8279 & 0.2121 & 0.8463 & 0.9824 & $7.79 \mathrm{E}+01$ & $9.60 \mathrm{E}+00$ \\
\hline GL3 & 0.8768 & 0.8198 & 0.3652 & 0.8393 & 0.9794 & $7.54 \mathrm{E}+01$ & $9.84 \mathrm{E}+00$ \\
\hline GL4 & 0.8934 & 0.811 & 0.9348 & 0.8399 & 0.9765 & $6.06 \mathrm{E}+01$ & $1.24 \mathrm{E}+01$ \\
\hline GL5 & 0.8992 & 0.8402 & 0.4907 & 0.8607 & 0.9861 & $7.36 \mathrm{E}+01$ & $1.05 \mathrm{E}+01$ \\
\hline GL6 & 0.9042 & 0.8356 & 0.8872 & 0.8526 & 0.9815 & $6.30 \mathrm{E}+01$ & $1.21 \mathrm{E}+01$ \\
\hline
\end{tabular}

407 The Korsmeyer-Peppas equation (Log cumulative percentage of drug released versus $\log$ time) analysis confirm that both diffusion and erosion mechanism were involved in releasing the drug from the matrix tablets when values of drug release exponent (n) is in the range of $0.45-0.89$. $[15,16]$ The calculated " $n$ " values for all tested product

411 falls within the range of $0.45-0.89$ indicating that the release of the drug particle is 412 due to both diffusion and erosion phenomena occurred throughout the course of 413 dissolution study.

415 Moreover, the generics can be interchangeable for brand/innovator products when the 416 difference between their dissolution efficiencies is within appropriate limits $( \pm 10 \%)$. $417[15,20]$ Hence, it can be concluded that GL1, GL2 and GL3 had similar drug release 418 profile with comparator (GL5) unlike GL4 and GL6 since their DE difference falls 419 within the range of $\pm 10 \%$.

\section{Conclusions}

421 This study evaluated the physicochemical quality and dissolution profile of six 422 commercially available glibenclamide brands. The physical characteristic tests 423 conducted on all tested product showed no deviation from the required specifications 424 for hardness, friability, weight variation, package integrity and labeling completeness. 425 All tested brands found to comply United States Pharmacopeia 38 monograph specification for their identification, label claim, content uniformity and dissolution.

427 However, significant difference with respect to dissolution profile among tested 428 brands GL4 and GL6 were confirmed with comparator product through model 429 independent approach. Additionally, DE values were studied and confirmed that GL4 
430 and GL6 were not therapeutically interchangeable with innovator product. These

431 statistically significant differences in assay and dissolution profiles associated with

432 the tested drugs are likely to reflect potential differences in clinical performance.

433 Therefore, properly controlled bio-equivalence studies are strongly recommended to

434 further investigate the potential problem that might associate with generic products.

\section{Acknowledgements}

437 My profound and sincere gratitude go to Cadila Pharmaceutical Private Limited 438 Company, Ethiopia for the generous donation of Working Standard and Reagents. I 439 would like to extend my thanks to Jimma University Drug Quality Testing and 440 Control Laboratory for providing necessary chemicals and reagents for this research.

\section{References}

443 1. Cosco D, Paolino D, Maiuolo J, Marzio L Di, Carafa M, Ventura CA, et al.

444 Non-micronized Products of Glibenclamide Tablets. Int J Pharm [Internet]. 2015;489(1-2):1-10. Available from: https://linkinghub.elsevier.com/retrieve/pii/S0378517315003646

447 2. Javaid A, Hasan R, Zaib A, Mansoor S. A comparative study of the effects of 448 hypoglycemic agents on serum electrolytes in the diabetic patients. Pak $\mathbf{J}$

449 Pharm Sci. 2007;20.

450 3. Population and Individual Bioequivalence Working Group of the Biopharmaceutics Coordinating Committee in the Office of Pharmaceutical Science. Guidance for Industry Establishing Bioequivalence Guidance for Industry Statistical Approaches to [Internet]. Vol. 4. Center for Drug Evaluation and Research (CDER) at the Food and Drug Administration (FDA).; 2001.48 p. Available from:

4. World Health Organization(WHO). Guidlines for the development of the measures to combat counterfiet drugs. Geneva, Switzerland: Department Essential of Drugs and Other Medicines; World Health Organization.;

460 5. World Health Organization. Effective medicines regulation : ensuring safety , 461 efficacy and quality. WHO Policy Perspect Med. 2003;1-6.

462 6. Kaur H, Green MD, Hostetler DM, Fernández FM, Newton PN. Antimalarial 
463

464

465

466

drug quality: Methods to detect suspect drugs. Therapy. 2010;7(1):49-57.

7. El-Sabawi D. Pharmaceutical evaluation of glibenclamide products available in the Jordanian market. African J Pharm Pharmacol. 2013;7(22):1464-70.

8. Shazly GA, Mahrous GM. Assessment of the physicochemical properties and in vitro dissolution of glibenclamide tablets marketed in Saudi Arabia. Dissolution Technol. 2014;21(4):61-6.

9. Blume H, Ali SL, Siewert M, et al. Pharmaceutical quality of glibenclamide products: a multinational postmarket comparative study. Drug Dev Ind Pharm $1993 ; 19: 2713-41$.

10. Suleman S, Zeleke G, Deti H, Mekonnen Z, Duchateau L, Levecke B, et al. Quality of Medicines Commonly Used in the Treatment of Soil Transmitted Helminths and Giardia in Ethiopia: A Nationwide Survey. PLoS Negl Trop Dis. $2014 ; 8(12)$.

11. Gebrezgabiher A, Yilma Z, Tadese E. Comparative In Vitro Quality Evaluation of Different Brands of Mebendazole Tablets, Comparative In Vitro Quality Evaluation of Different Brands of Mebendazole Tablets ,. J PharmaSciTech. 2017;5(2):98-101.

12. Kahsay G, G/Egziabher A. Quality Assessment of the Commonly Prescribed Antimicrobial Drug, Ciprofloxacin Tablets, Marketed in Tigray, Ethiopia. Momona Ethiop J Sci. 2010;2(1).

13. Kassaye L., Genete G. Evaluation and comparison of in-vitro dissolution profiles for different brands of amoxicillin capsules. Afr Health Sci [Internet]. 2013;13(2):369-75. Available from:

http://www.embase.com/search/results?subaction=viewrecord\&from=export\&i $\mathrm{d}=\mathrm{L} 369785006 \% 5 \mathrm{Cnhttp} / /$ www.ajol.info/index.php/ahs/article/download/935 24/82949\%5Cnhttp://dx.doi.org/10.4314/ahs.v13i2.25

14. US Pharmacopoeia National Formulary, USP 38/NF 33, United States Pharmacopoeial Convention. Rockville, MD, USA; 2015.

15. Anderson NH, Bauer M, Boussac N, Khan-Malek R, Munden P, Sardaro M. An evaluation of fit factors and dissolution efficiency for the comparison of in vitro dissolution profiles. J Pharm Biomed Anal. 1998;

16. Costa P, Sousa Lobo JM. Modeling and comparison of dissolution profiles. European Journal of Pharmaceutical Sciences. 2001.

17. Watson R. NOTE FOR GUIDANCE ON VALIDATION OF ANALYTICAL 
PROCEDURES: TEXT AND METHODOLOGY (CPMP/ICH/381/95). In:

BMJ (Clinical research ed). European Medicines Agency; 2006. p. 873.

18. Singh SK, Srinivasan KK, Gowthamarajan K, Prakash D, Gaikwad NB, Singare DS. Influence of formulation parameters on dissolution rate enhancement of glyburide using liquisolid technique. Drug Dev Ind Pharm. 2012;38(8):961-70.

19. Shah VP, Lesko LJ, Fan J, Fleischer N, Handerson J, Malinowski H, et al. FDA guidance for industry 1 dissolution testing of immediate release solid oral dosage forms. Vol. 4, Dissolution Technologies. 1997. 15-22 p.

20. Awofisayo S, Nnamdi J, Uwah A. Comparative Evaluation of the Quality Control Parameters and Hypoglycemic Drug Effect of Some Brands of Glibenclamide Tablet. J Adv Med Pharm Sci. 2015;2(1):29-35.

21. Siepmann J, Peppas NA. Modeling of drug release from delivery systems based

22. Del Tacca M, Pasqualetti G, Di Paolo A, Virdis A, Massimetti G, Gori G, et al. on hydroxypropyl methylcellulose (HPMC). Advanced Drug Delivery

24. Eichie FE, Arhewoh MI, Isesele JE, Olatunji KT. In vitro assessment of quality control parameters of some commercially available generics of amlodipine besylate in Nigerian drug market. Int J Heal Res. 2011;4(1):57-61.

25. Genazzani AA, Pattarino F. Difficulties in the production of identical drug products from a pharmaceutical technology viewpoint. Drugs in R and D. 2008.

27. Smith JC, Tarocco G, Merazzi F, Salzmann U. Are generic formulations of carvedilol of inferior pharmaceutical quality compared with the branded formulation? Curr Med Res Opin. 2006;

28. Awofisayo S, Nnamdi J, Uwah A. Comparative Evaluation of the Quality Control Parameters and Hypoglycemic Drug Effect of Some Brands of 
bioRxiv preprint doi: https://doi.org/10.1101/860163; this version posted November 29, 2019. The copyright holder for this preprint (which

was not certified by peer review) is the author/funder, who has granted bioRxiv a license to display the preprint in perpetuity. It is made available under aCC-BY 4.0 International license.

532

533

534

535

536

537

538

539

540

541

542

543

544

545

546

547

548 


\section{Fig 7. Dissolution profile of tested drugs at $8.5 \mathrm{pH}$ phosphate buffer}

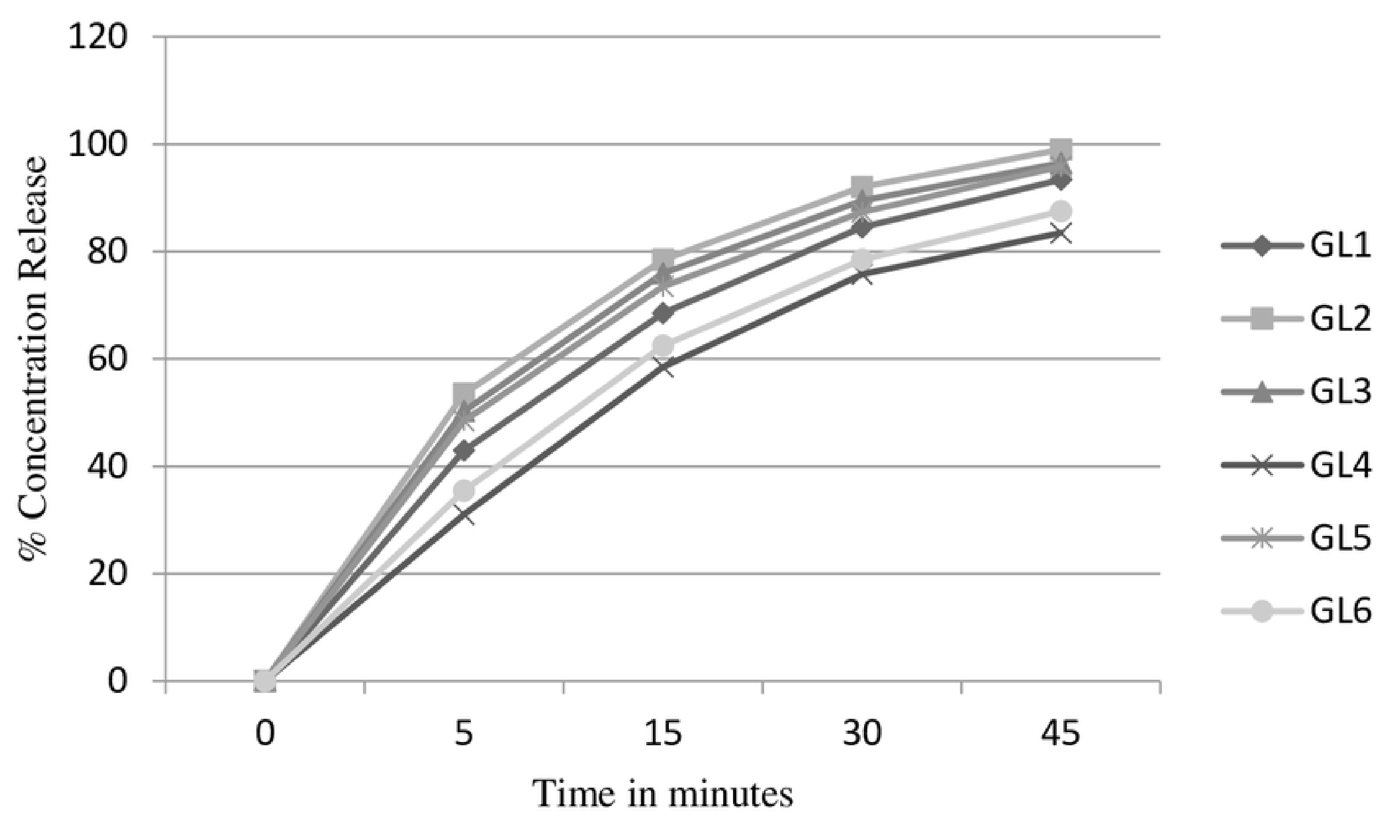


Fig 1. Chemical structure of Glibenclamide

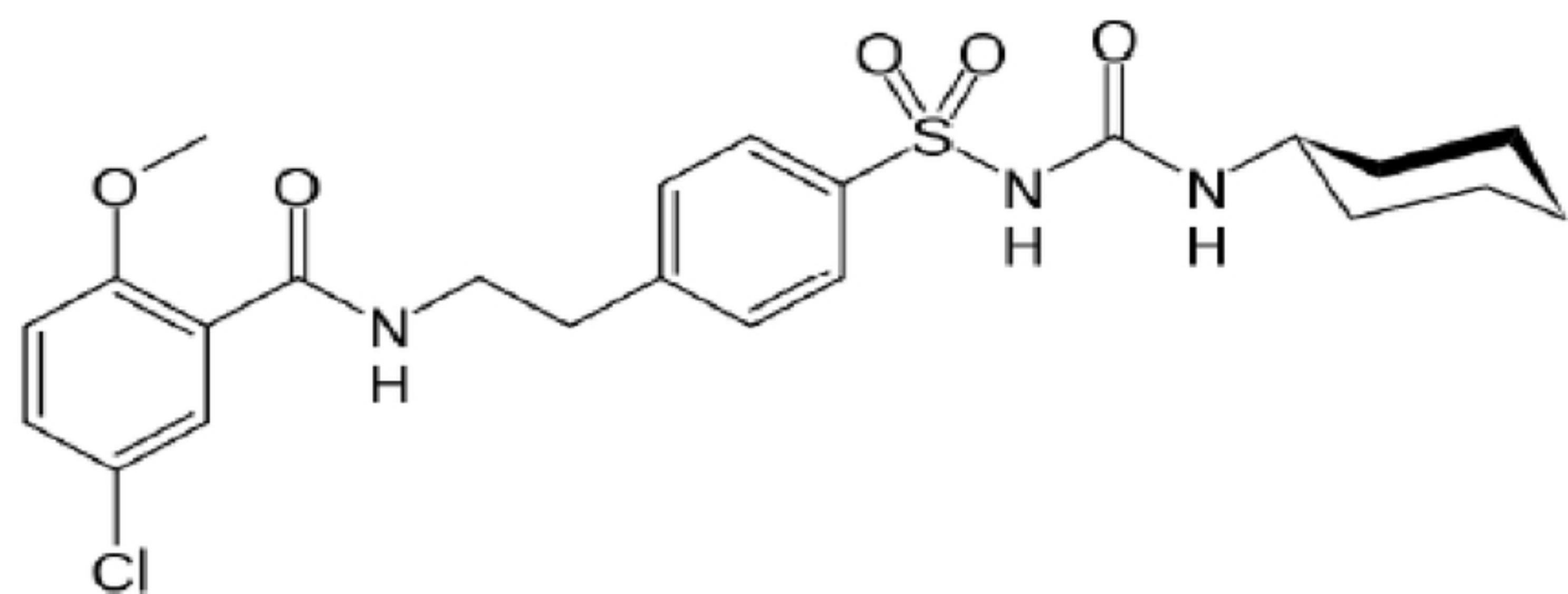


Fig 2. System linearity test result at 5 different concentration of the standard $(n=3)$

\section{Method Linearty}

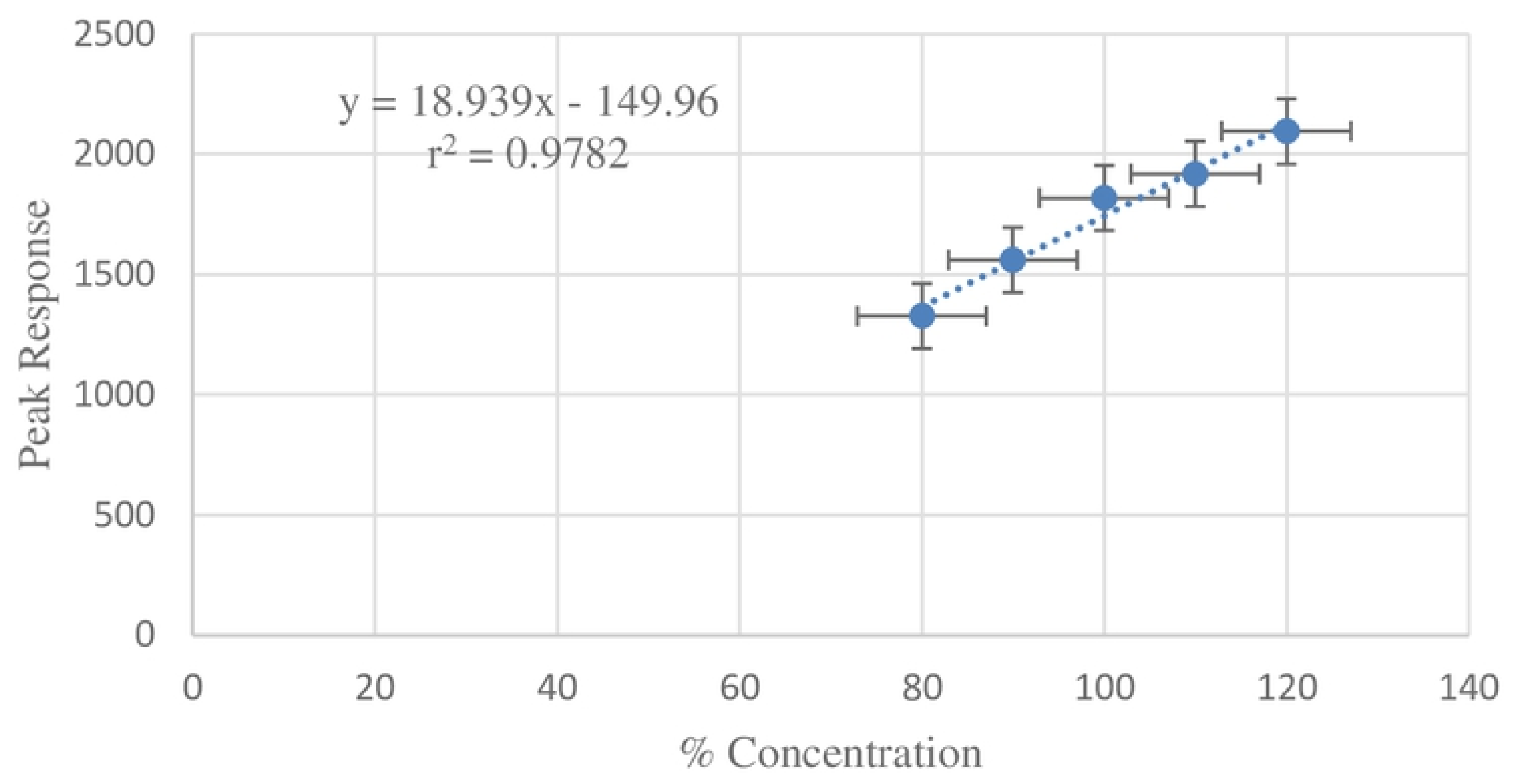


Fig 3. Blank chromatogram

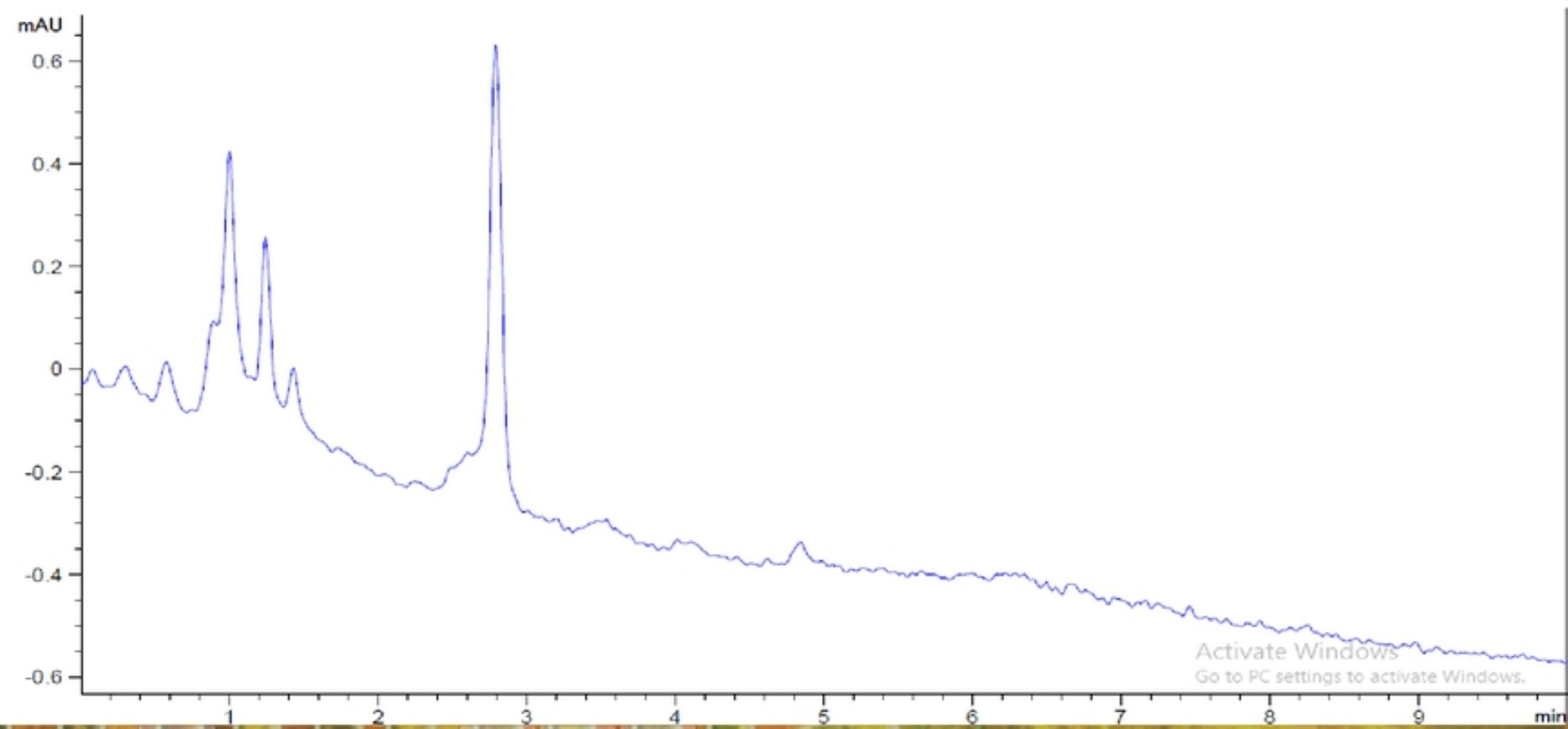




\section{Fig 4. Reference chromatogram}

DAD1 A, Sig=254,4 Ref=360,100 (GLIBENCLAM ... Y20160827 GLIBENCLAMID ASSAY mAU

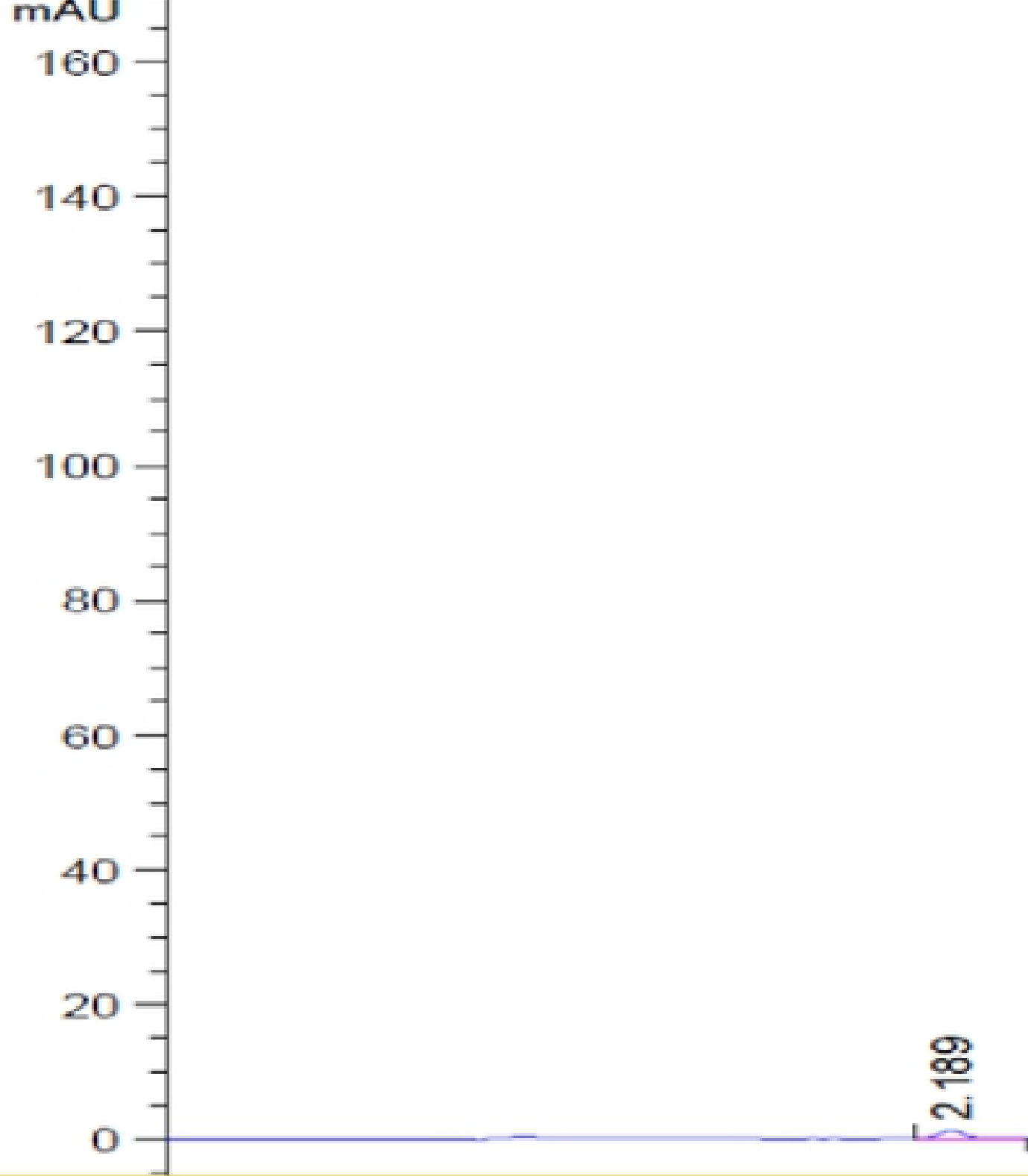




\section{Fig 5. Sample chromatogram}

DAD1 A, Sig=254,4 Ref=360,100 (GLIBENCLAM ... Y20160827 GLIBENCLAMID ASSAY mAU J

175

-

$150-$

-

125

-

100

75 -

$50-$

25

-

0 工

:

ळี 
Fig 6. Dissolution profile of tested drugs at $7.5 \mathrm{pH}$ phosphate buffer

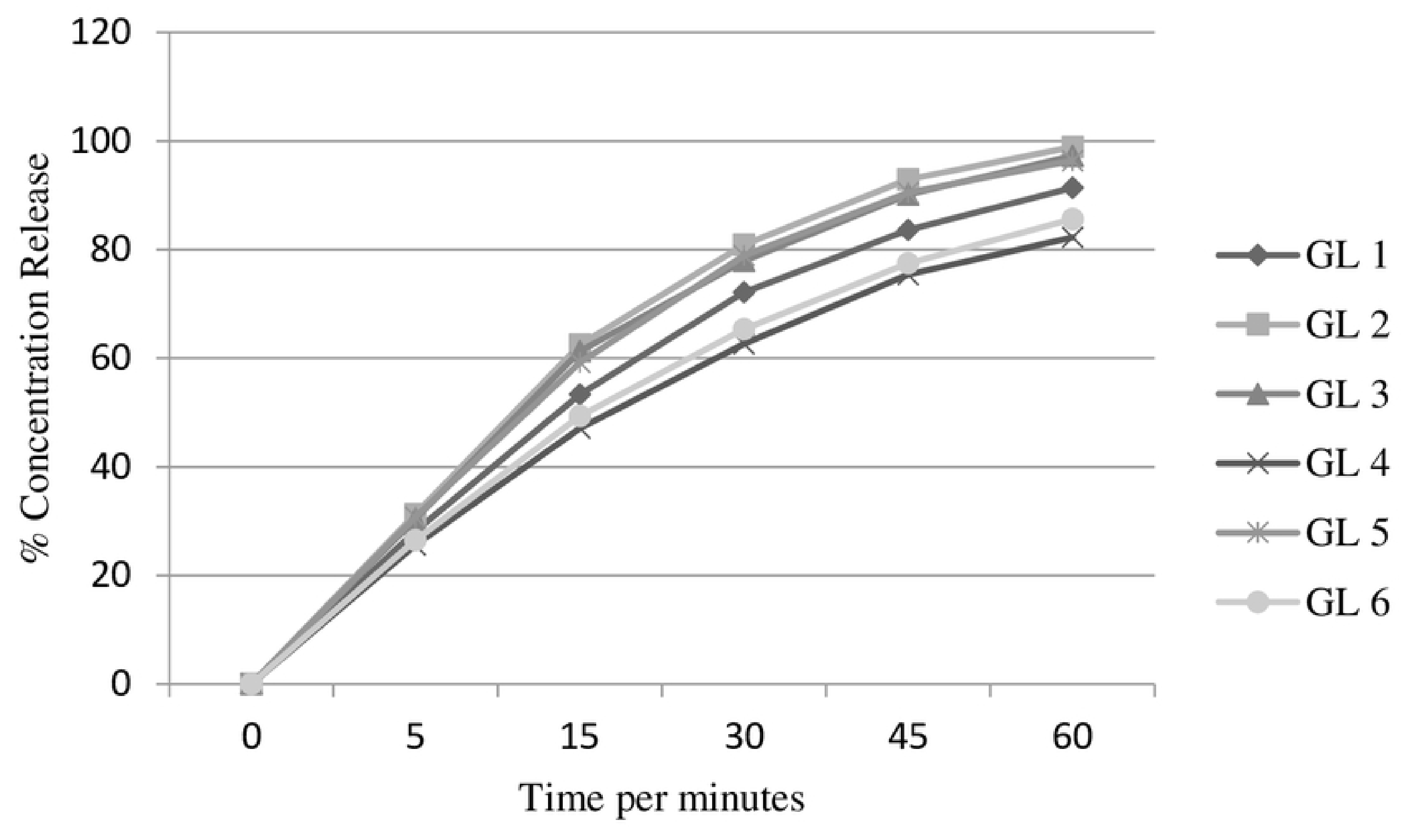

